\title{
Britannica
}

In Verbindung mit dem Seminar für englische Sprache und Kultur an der Hamburgischen Universität herausgegeben von

\section{Emil Wolff}

Heft 9 



\title{
Jonathan Swift Gedanken und Schriften über Religion und Kirche
}

\author{
Von \\ Hans Reimers
}

Friederichsen, de Gruyter \& Co. m.b.H. / Hamburg 1935 
